\title{
The megalopa and early juvenile development of Hepatus pudibundus (Crustacea: Brachyura: Aethroidea) reared from neuston samples
}

\author{
Maria L. Negreiros-Fransozo 1, 2; Adilson Fransozo \& Gustavo L. Hirose \\ ${ }^{1}$ Núcleo de Estudos em Biologia, Ecologia e Cultivo de Crustáceos, Departamento de Zoologia, Instituto de Biociências, \\ Universidade Estadual Paulista. 18618-000 Botucatu, São Paulo, Brasil. E-mail: mInf@ibb.unesp.br \\ ${ }^{2}$ Corresponding author.
}

\begin{abstract}
Hepatus pudibundus (Herbst, 1785) is a crab commonly found in shallow waters of the Western Atlantic. Its larval and early post-larval morphology have already been described from laboratory hatched material. Around 200 megalopae of $H$. pudibundus were collected in neuston samples from the Ubatuba region, Brazil, during the summer of 2005-2006 and were successfully reared under laboratory conditions. The size of the megalopae obtained in the neuston was similar to those specimens previously described in the literature, except that the juvenile crab stages reared in the laboratory were slightly larger, probably due to the better feeding conditions in the laboratory. The duration of the juvenile stages was shorter in the present study than in previous attempts at laboratory rearing, even if conditions appeared to be similar. The main differences observed between studies were in megalopal morphology, which may be attributable to intraspecific variation but, possibly, also due to differences in levels of detail than previously performed.
\end{abstract}

KEY WORDS. Aethridae; crab; size difference, Brazilian coast.

RESUMO.A megalopa e o desenvolvimento juvenil inicial de Hepatus pudibundus (Crustacea: Brachyura:Aethroidea) criado a partir de amostras de neuston. Hepatus pudibundus (Herbst, 1785) é um caranguejo comumente encontrado em águas rasas do Atlântico Ocidental. O desenvolvimento larval completo e a sua morfologia pós-larval já são conhecidos a partir de fêmeas ovígeras. Cerca de 200 megalopas de $H$. pudibundus foram coletadas no neuston durante o verão de 2005-2006, na região de Ubatuba, São Paulo, Brasil e criadas com sucesso sob condições de laboratório. O tamanho da megalopa obtida no neuston foi semelhante àquela dos exemplares descritos previamente na literatura, mas os estágios juvenis criados no laboratório foram ligeiramente maiores na fase inicial, provavelmente devido às melhores condições de alimentação no laboratório. A duração dos estágios juvenis foi menor na presente investigação, do que no estudo anterior, mesmo sob condições laboratoriais similares. As principais diferenças entre os estudos foram com relação à morfologia da megalopa, as quais podem ser atribuídas às variações intra-específicas, mas possivelmente, também, ao nível de detalhe empregado previamente.

PALAVRAS-CHAVE. Aethridae; caranguejo; diferença no tamanho, costa brasileira.

The brachyuran crab Hepatus pudibundus (Herbst, 1785) is commonly found in shallow waters of the Western Atlantic, from South Carolina, USA, to Rio Grande do Sul, Brazil (MeLo 1996) and lives partially burrowed in the soft substrate.

Its general biology, growth and some reproductive aspects are well documented for the southeastern Brazilian coast (Mantelatto \& Fransozo 1992, 1994, Reigada et al. 1994, Mantelatto et al. 1995a, b, Reigada \& Negreiros-Fransozo 1995, 1999, Mantelatto \& Petracco 1997). The complete larval and post-larval development was described from laboratory reared materials (Rieger \& Hebling 1993, Hebling \& Rieger 2003).

Further, eight juvenile stages were obtained by HebLing \& Rieger (2003), with the external differentiation of the secondary sexual characters occurring on the third juvenile stage. According to Rieger \& Hebling (1993), H. pudibundus goes through 4, 5 or 6 larval stages before molting to the megalopa stage. The larval development is known for other Hepatus species including, Hepatus epheliticus (Linnaeus, 1763), by CostLow $\&$ Bookнout (1962), with five zoeal stages. After that, they enter the juvenile phase.

The littoral zone of São Paulo is relatively diverse in terms of brachyuran species, with about 189 of the 330 species known from Brazil occurring in this transitional biogeographical area (Melo 1996). The larval development is known for only about $17 \%$ of these species and many are in need of updating in terms of morphological details, mainly in the setation of appendages.

In this report, we investigate morphological differences within $H$. pudibundus for wild-caught megalopae versus those raised in the laboratory from eggs. Data on the growth and development of the juvenile stages, reared in the laboratory from these megalopae are also presented and compared to results obtained elsewhere.

Revista Brasileira de Zoologia 25 (4): 608-616, December, 2008 


\section{MATERIAL AND METHODS}

Live megalopae were obtained from neuston samples collected at night in the summer of 2005-2006 from the Ubatuba region, São Paulo, Brazil. The larvae were separated from the samples with a Pasteur pipette and using a light source. Each megalopa was transferred to a clean $50 \mathrm{ml}$ container filled with filtered sea water from the collecting site. Freshly hatched Artemia sp. nauplii (ad libitum) and pellets of fish food (artificial food) were added as food. Each closed container was transported to the laboratory at Botucatu inside thermic boxes. In the laboratory, the containers were examined from the presence of exuviae, which were removed and then the water and the food were changed. Rearing was undertaken in a climatic controlled room at $25 \pm 1^{\circ} \mathrm{C}$ and natural photoperiod. Feeding was offered every day, and the water changed every other day. The adopted rearing procedures were similar the techniques used by Hebling \& RIEGER (2003) in order to facilitate data comparison.

Dead larvae or juvenile crabs and exuviae were preserved in $80 \%$ ethanol and deposited in the NEBECC (Crustacean Biology, Ecology and Culture Study Group) Larval Collection under accession numbers 0103 to 0140 . Morphometric data were obtained using an optical compound (Axioskop 2) or stereo microscope (SV6) connected to an imaging system (Axiovision, Zeiss). The carapace width (CW) was measured. The description sequence and seta terminology follow those indicated by Pohle \& Telford (1981) and Pohle et al. (1999). Setae are described from proximal to distal portion of the body or the appendages.

Growth was determined based on data of carapace width (CW) and age (days) obtained for each juvenile stage. Data were $\log$ transformed and analyzed using linear regression. Analysis of covariance (Ancova, $\alpha=0.05$ ) was used to test for differences in growth data with those of Hebling \& Rieger (2003) based on the slope and intercept of growth lines.

\section{RESULTS}

Approximately 200 megalopae were reared successfully under laboratory conditions to the early juvenile stages, but only 40 specimens reached the $8^{\text {th }}$ juvenile stage. The size of the megalopa is $1.0 \pm 0.11 \mathrm{~mm}$ of $\mathrm{CW}$.

In the laboratory, megalopa and juvenile crabs did not accept artificial food, only Artemia sp. nauplii.

\section{Megalopa}

Carapace (Fig. 1) rectangular, longer than wide $(\mathrm{CL}=1.16$ $\pm 0.18 \mathrm{~mm}, \mathrm{CW}=1.0 \pm 0.11 \mathrm{~mm}$ ), with sparse setae. Anterolateral margins with a round protuberance. Rostrum strongly deflected ventrally.

Antennule (Fig. 2) with inner unsegmented flagellum bearing five simple setae; outer flagellum 5 -segmented with 0 , 5, 6, 4 and 0 aesthetascs. Antenna (Fig. 3) with eight-segmented bearing $0,0,2,0,3,0,2$ and 4 simple setae.

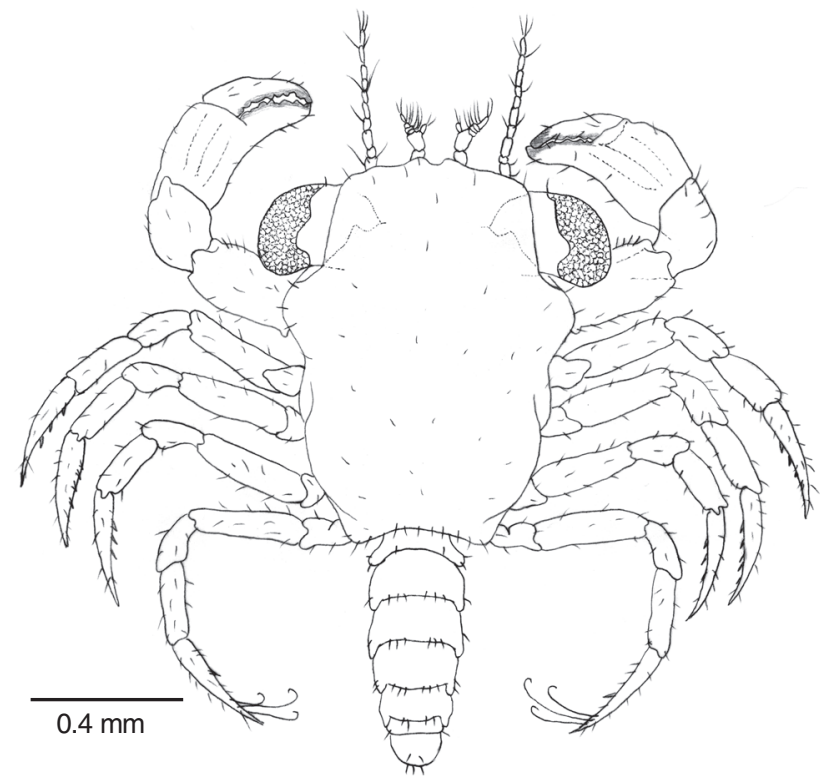

Figure 1. Dorsal view of megalopa of Hepatus pudibundus.

Mandible (Fig. 4) with two-segmented palp bearing two plumose setae and 9-10 serrate setae on distal segment. Maxillule (Fig. 5) with protopod bearing two plumose setae; endopod two-segmented with two plumose setae and two simple setae on proximal and distal segment, respectively. Basial endite with two plumose setae, 18-23 serrate setae and three proximal plumose setae; coxal endite with $12-15$ plumose setae. Maxilla (Fig. 6) with endopod unsegmented and bearing four short and proximal plumose setae. Scaphognathite with 58 marginal plumose setae and six simple setae on its blade surface. Basial and coxal endite distinctly bilobed, both with numerous and predominantly plumose setae as figured. First maxilliped (Fig. 7) Endopod with one plumose setae basally and five terminal simple setae distally. Exopod two-segmented with two and three plumose setae. Basial endite with around 18 plumodenticulate setae and two simple setae. Epipod with 18-19 simple setae.

Second maxilliped (Fig. 8) Protopod bearing two plumose setae and two simple setae. Endopod five-segmented with one simple setae, one simple setae, 4-5 plumose setae, 2-3 plumose setae, and five serrate setae. Exopod with four plumose setae. Epipod with nine simple setae. One branchial rudiment is present. Third maxilliped (Fig. 9) Endopod five-segmented with a conspicuous crista dentata on first segment and bearing 6-8 simple setae and 18 plumose setae; 7-9 plumose setae and three simple setae on second segment; three plumose setae on third segment; one plumose setae, nine serrate setae and one simple setae on fourth segment; and 5-6 serrate setae on fifth segment (Figs 10-12). One branchial rudiment is present. Exopod reduced with five simple setae on first segment. Protopod with eight plumose setae. Epipod with one plumose setae and 14 simple setae. 

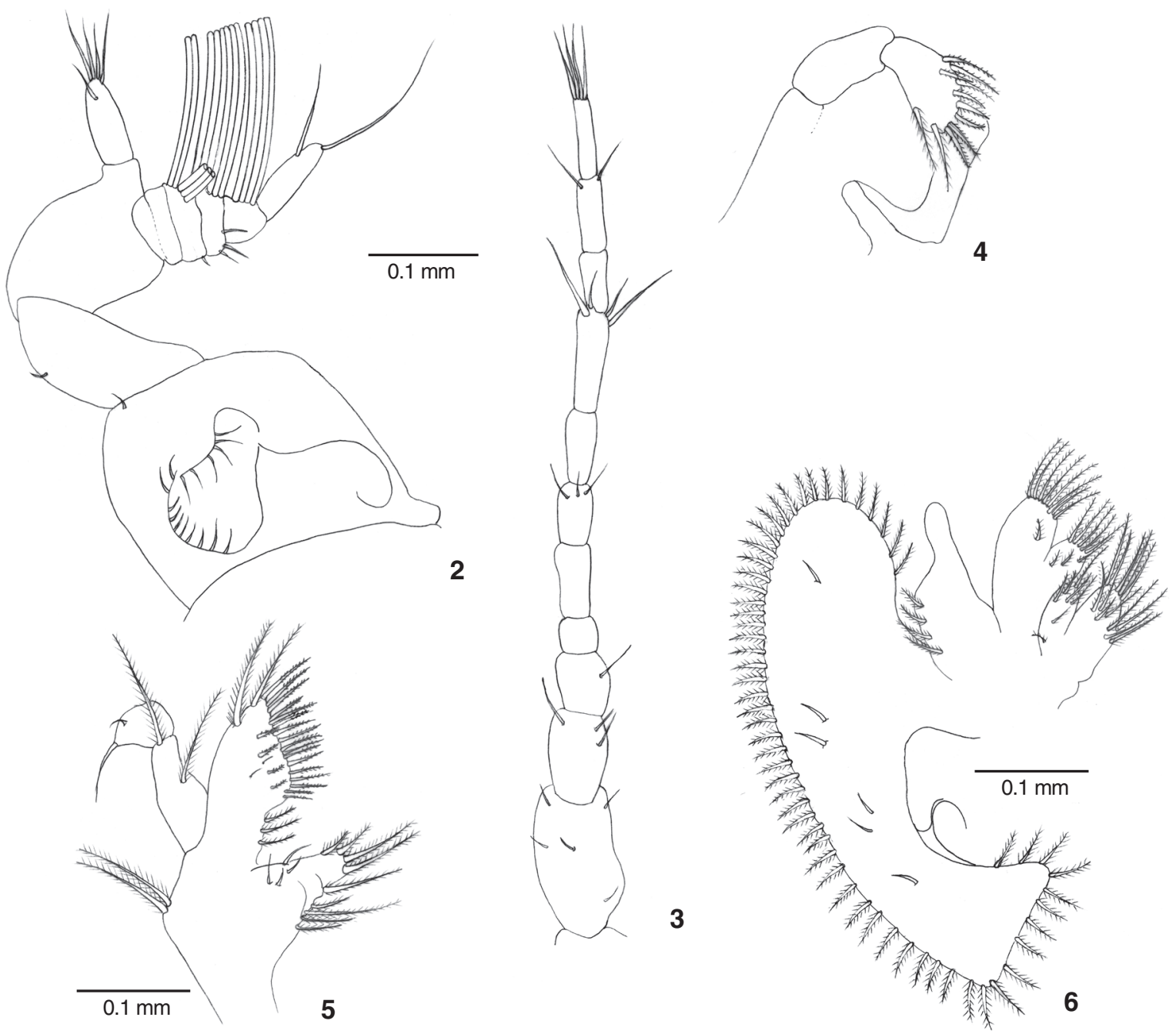

Figures 2-6. Megalopa of Hepatus pudibundus: (2) antennule; (3) antenna; (4) mandible; (5) maxillule; (6) maxilla.

Chelipeds (Figs 1 and 13) symmetrical and robust; ischium with granular inner margin; basis with 10 plumose setae.

Pereiopods (Figs 14-16) P2, P3 and P4 with basis bearing 10 plumose setae; inner margin of the dactyls with 3-5, 5-6 and 6-7 serrate setae, respectively; P5 with the inner margin of the dactyl bearing one serrate setae and three long serrate hooked setae apically.

Pleopods (Figs 17-20) birramous bearing 19, 19, 16 and 16 plumose setae on exopod, respectively on $\mathrm{Pl}_{1}$ to $\mathrm{Pl}_{4}$; endopods with three cincinnuli each. Abdomen and telson with a few sparse simple setae. Uropod (Fig. 21) with protopod bearing one plumose seta and exopod with 8-9 plumose setae.

\section{Development of juveniles}

The duration of the megalopa and juvenile crab stages and their respective carapace width are presented in table I.
Table I. Mean values of carapace width (CW) and age (intermolt period, accumulated in days (Ac) for the megalopa and each juvenile crab stage.

\begin{tabular}{lcccccc}
\hline \multirow{2}{*}{ Stages } & \multicolumn{3}{c}{ Present paper } & \multicolumn{3}{c}{ HebLING \& RIEGER (2003) } \\
\cline { 2 - 7 } & CW & \multicolumn{1}{c}{ sd } & Ac (days) & CW & sd & Ac (days) \\
\hline Mega & 1.00 & 0.11 & 36.8 & 1.12 & - & 38.2 \\
I & 1.99 & 0.10 & 46.3 & 1.66 & 0.17 & 46.9 \\
II & 2.73 & 0.17 & 58.1 & 2.50 & 0.26 & 58.7 \\
III & 3.44 & 0.34 & 77.7 & 3.37 & 0.88 & 77.2 \\
IV & 4.39 & 0.43 & 99.4 & 4.41 & 1.49 & 108.2 \\
V & 5.38 & 0.53 & 125.1 & 5.42 & 1.96 & 146.3 \\
VI & 6.53 & 0.49 & 160.0 & 7.11 & 2.21 & 210.6 \\
VII & 7.91 & 0.47 & 201.5 & 8.96 & 2.21 & 258.5 \\
VIII & 9.11 & 0.32 & 224.0 & 10.96 & 2.21 & 369.0 \\
\hline
\end{tabular}




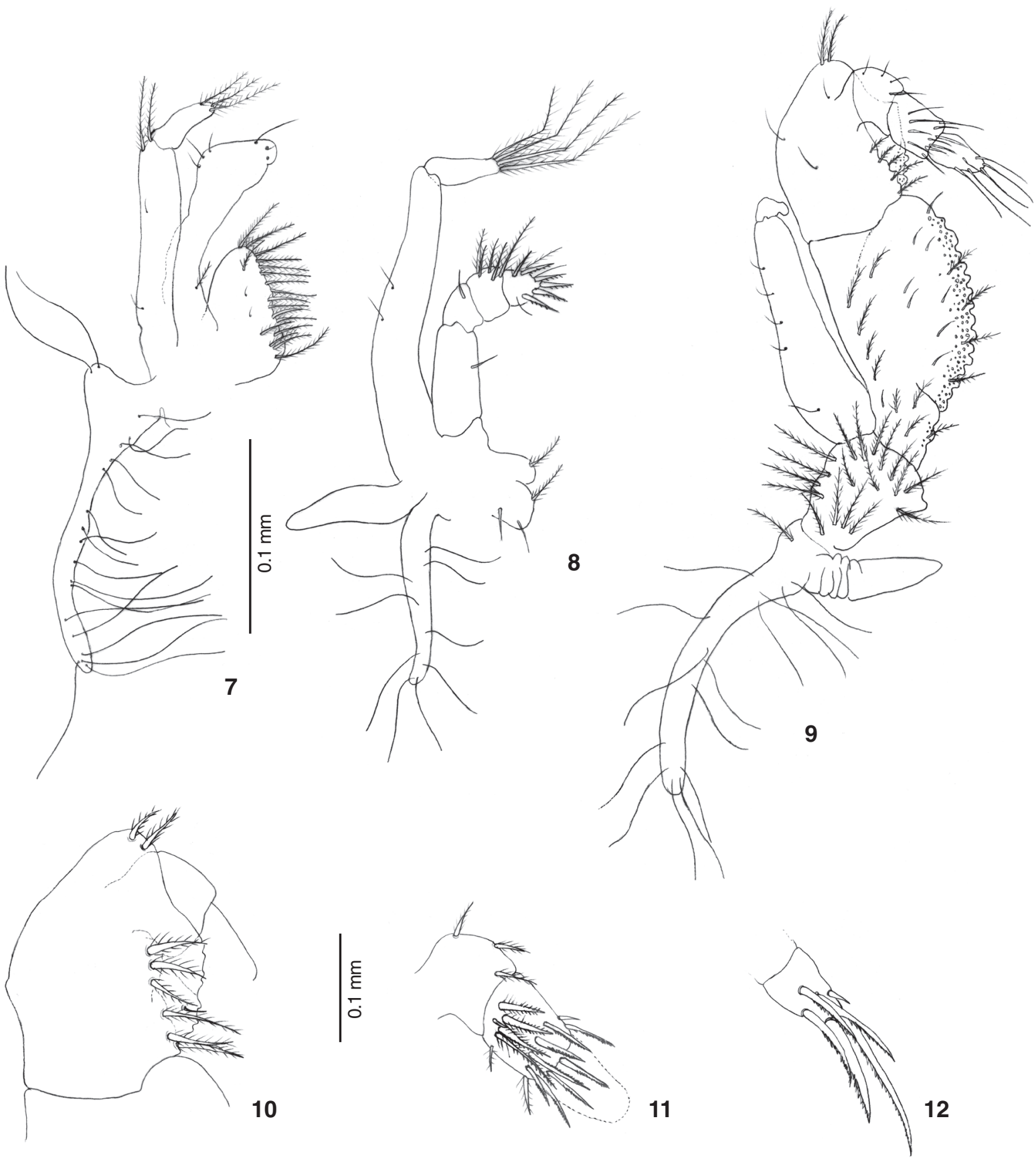

Figures 7-12. Megalopa of Hepatus pudibundus: (7) first maxilliped; (8) second maxilliped; (9) third maxilliped; (10-12) setation details of merus, carpus, propodus, and dactylus of the third maxilliped, respectively.

During juvenile development, the most significant changes are related to the appearance of the secondary sexual characters. In the first juvenile stages, the shape of the abdomen is similar for both sexes as is the presence of four rudimentary pleopods. In the second juvenile stage, there are no pleopods on the ab- domen. In the third juvenile stage, males have two pairs of unirramous pleopods on the first and second somites, whereas females have four pairs of birramous pleopods on the second to fifth somites, respectively. These pleopods are very rudimentary, bearing no seta. 

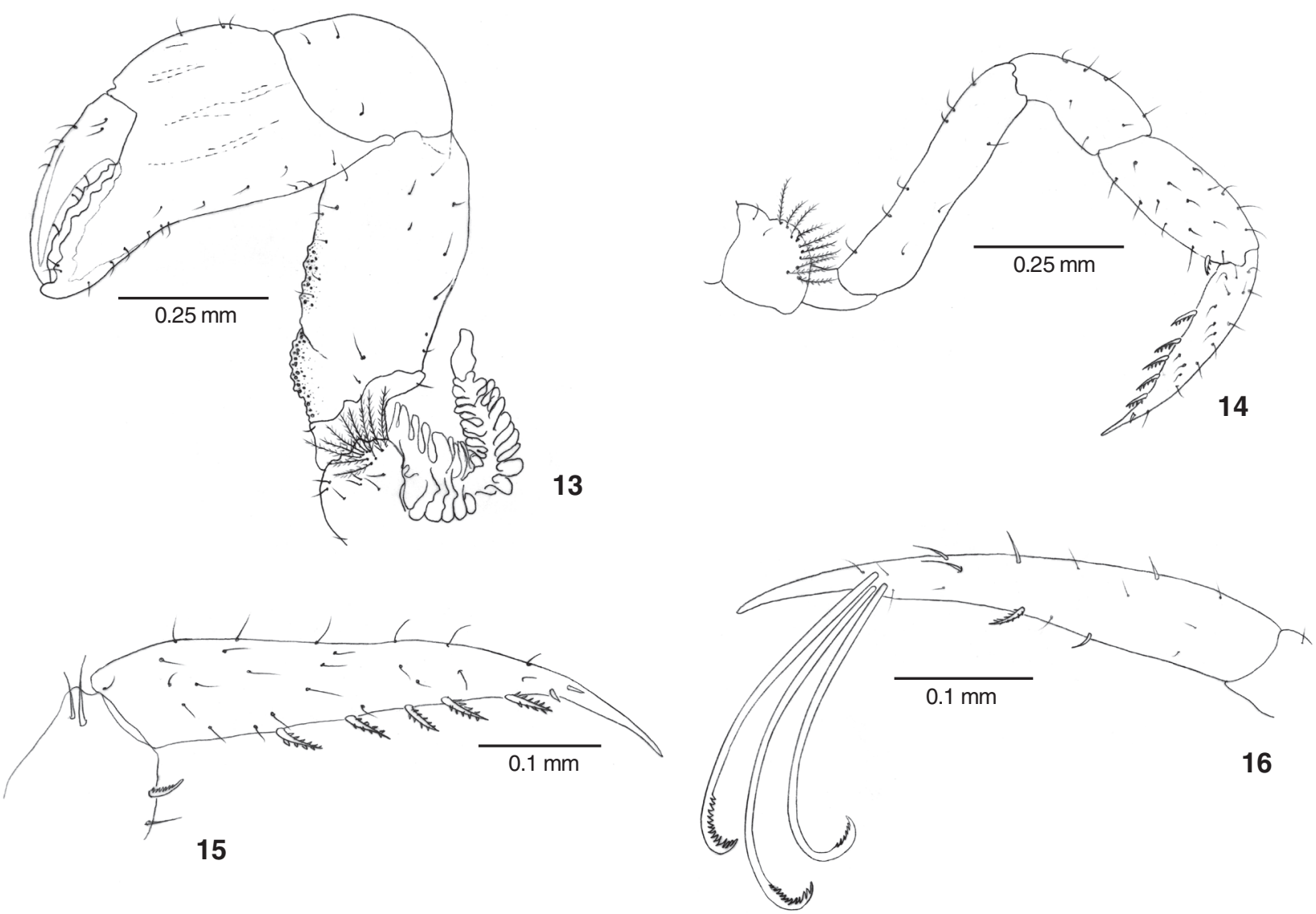

Figures 13-16. Megalopa of Hepatus pudibundus: (13) cheliped; (14) pereiopods; (15) dactyl of the 4 pereiopod; (16) dactyl of 5 pereiopod.

The growth of this species differs significantly (Ancova, "a", $\mathrm{p}<0.01$, and " $\mathrm{b}, \mathrm{p}=0.57$ ) between specimens reared by Hebling \& Rieger (2003) and those of the present study. Apparently, during the previous study a longer intermolt period was observed for each juvenile stage. This difference tends to increase as the juvenile development proceeds (Fig. 22).

\section{DISCUSSION}

For many years, the calappid and hepatid crabs were grouped in a same superfamily (Calappoidea). Recently, NG et al. (2008) have mentioned that the Hepatinae and Oethrinae belong to Aethridae, Aethroidea and Calappidae and Matutidae should be included in other superfamily (Calappoidea). The complete larval development of the representatives of Aethridae is poorly known, from which only $H$. epheliticus and $H$. pudibundus were described with respect to their larval development by Costlow \& Bookhout (1962) and Rieger \& Hebling (1993), respectively.

The sizes of the megalopae of $H$. epheliticus ( $\mathrm{CW}=0.86$ $\mathrm{mm}$ ) and $H$. pudibundus (CW $=1.12 \mathrm{~mm}$ from Rieger \& Hebling (1993) and CW $=1.00 \mathrm{~mm}$ present study) are very similar.
A detailed morphological comparison between these two species based on previous and present studies are presented in table II. Within species, the main differences can be attributed to intraspecific variation or differences in level of detail between descriptions.

Interspecifically, our analysis shows that there is a general similarity of the megalopa in the carapace, both Hepatus species having a deflected rostrum, enlarged anterolateral margins and bearing small simple setae. Both species also share dactyls of the fifth pereiopod having three long hooked serrate and two-segmented mandibular palp. The antennulle of both species of Hepatus share an unsegmented inner flagellum, but the outer flagellum of the antennulle differs between species. The setation of the maxillule is distinct, with that of the protopod being most distinct $(H$. epheliticus $=3$ plumose setae, $H$. pudibundus $=2$ plumose setae). The number of plumose setae on the scaphognathite does not overlap between species. The first maxilliped setation also differed among species.

The complex setation of the second and third maxillipeds indicates variations of setae number and type, but it is difficult to separate them using this feature. Pleopods and uro- 

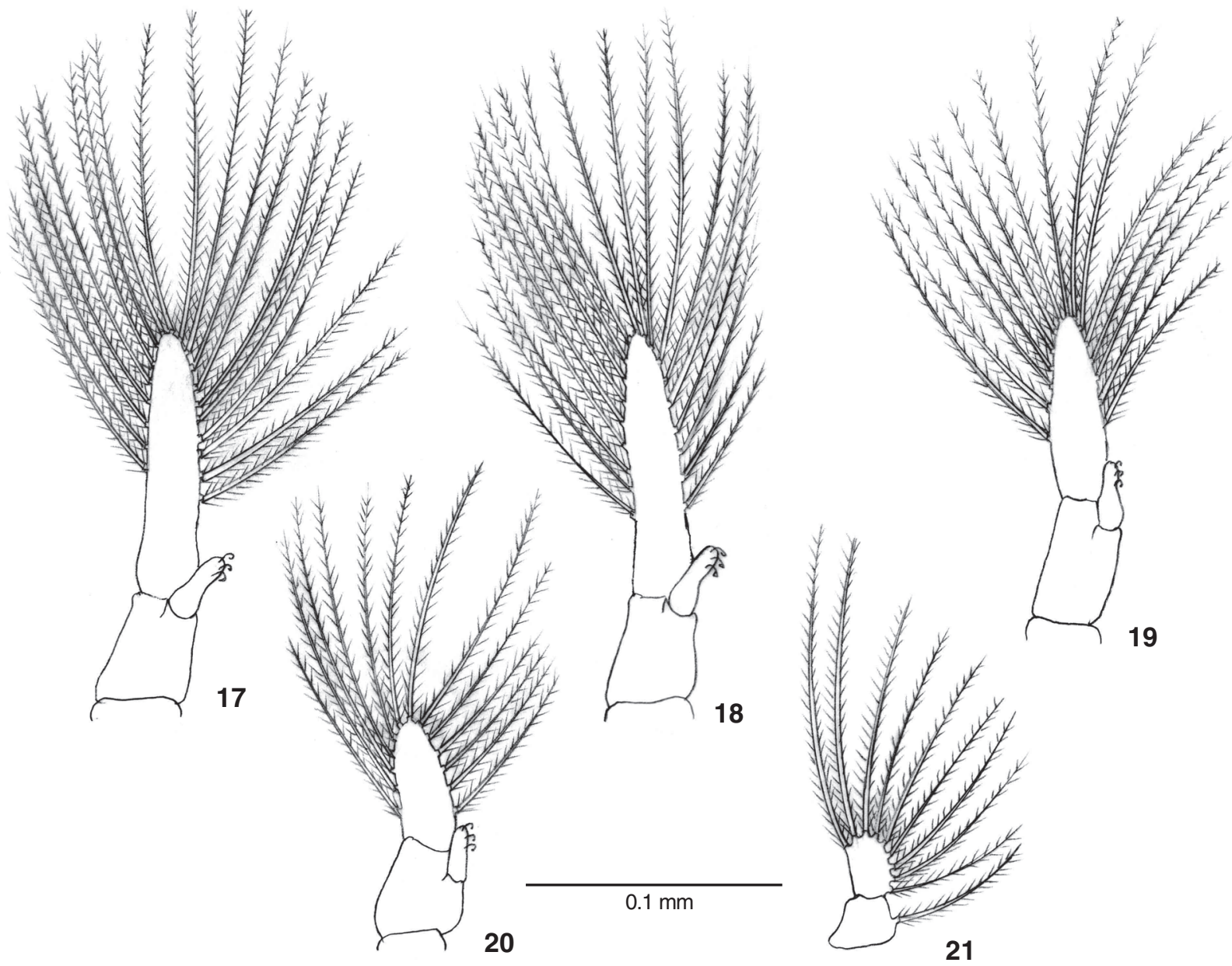

Figures 17-21. Megalopa of Hepatus pudibundus: (17-20) pleopods 1-4, respectively; (21) uropod.
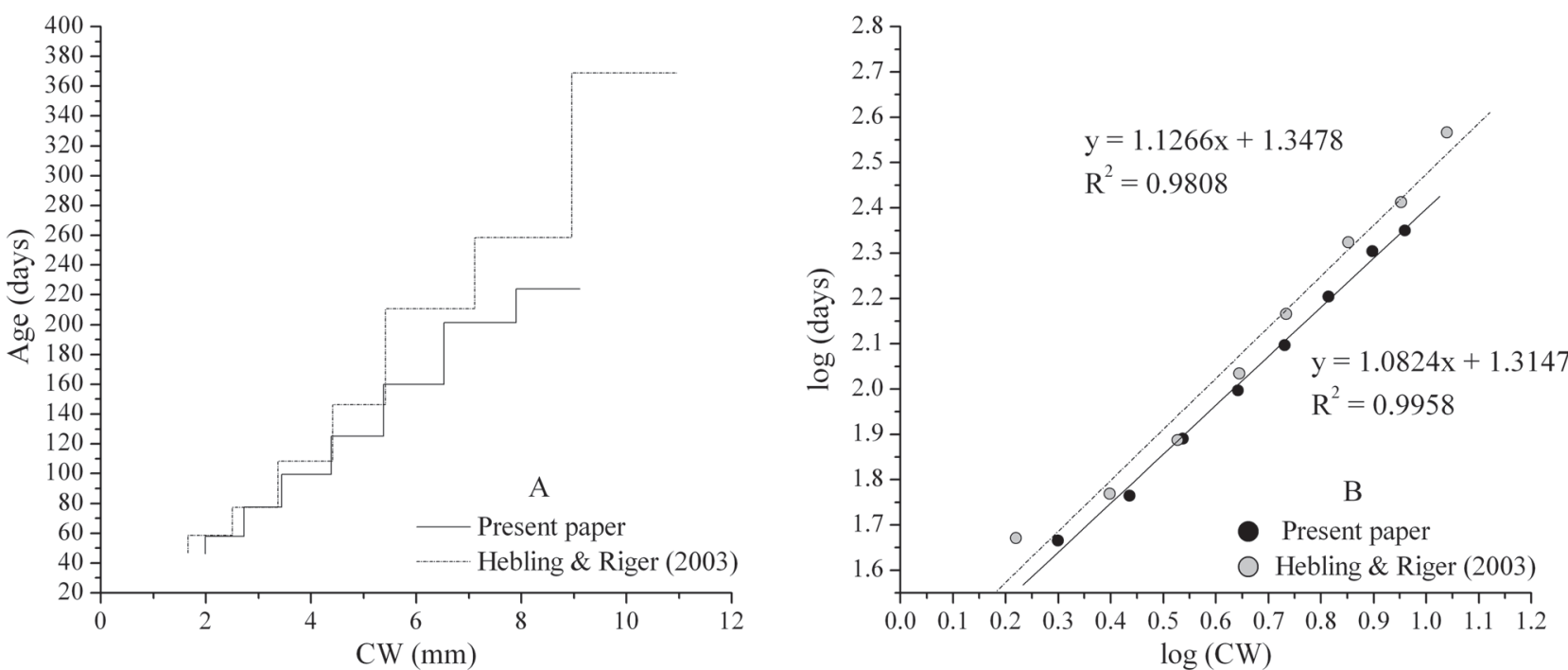

Figure 22. Relationship between CW vs. Age: (A) growth curve of duration in days and molt increment at each juvenile stage; (B) comparison of linear growth data (log) between the present data and HeBLING \& RIEGER (2003). Ancova, p $<0.01$. 
Table II. Comparison of megalopae characters within Hepatus.

\begin{tabular}{|c|c|c|c|}
\hline Characters & $\begin{array}{c}\text { Hepatus epheliticus } \\
\text { CostLow \& Boокночт (1962) }\end{array}$ & $\begin{array}{l}\text { Hepatus pudibundus } \\
\text { RIEGER \& HEBLING (1993) }\end{array}$ & $\begin{array}{l}\text { Hepatus pudibundus } \\
\text { Present study }\end{array}$ \\
\hline \multirow[t]{2}{*}{ Size } & $\mathrm{CL}=1.1 \mathrm{~mm} *$ & $\mathrm{CL}=1.24 \mathrm{~mm}^{*}$ & $\mathrm{CL}=1.16 \mathrm{~mm}$ \\
\hline & $\mathrm{CW}=0.86 \mathrm{~mm}^{*}$ & $\mathrm{CW}=1.12 \mathrm{~mm} *$ & $\mathrm{CW}=1.00 \mathrm{~mm}$ \\
\hline \multirow[t]{3}{*}{ Carapace } & numerous short hairs & some simple setae & sparse simple setae \\
\hline & $\begin{array}{l}\text { anterolateral margins terminates as } \\
\text { slightly thickened knob }\end{array}$ & $\begin{array}{l}\text { anterolateral margins with a rounded } \\
\text { protuberance }\end{array}$ & $\begin{array}{l}\text { anterolateral margins with a rounded } \\
\text { protuberance }\end{array}$ \\
\hline & $\begin{array}{l}\text { rostrum short with median knob } \\
\text { deflected ventrally }\end{array}$ & rostrum small and deflected ventrally & Rostrum deflected ventrally \\
\hline \multirow[t]{3}{*}{ Chelipeds** } & Simple setae & Symmetrical with simple setae & Symmetrical and robust \\
\hline & & & -ischium with crista dentate \\
\hline & & & - basis with 10 plumose setae \\
\hline \multirow[t]{2}{*}{ Pereiopods** } & P5 with 3 long serrate setae* & P5 with long hooked serrate seta & $\begin{array}{l}\text { P2, P3 and P4 - basis with } 10 \text { plumose } \\
\text { setae; inner margin of the dactyls with } \\
3-5,5-6 \text { and } 6-7 \text { serrate setae, } \\
\text { respectively. }\end{array}$ \\
\hline & & & $\begin{array}{l}\text { P5 -inner margin of the dactyl with } 1 \\
\text { serrate seta and } 3 \text { long hooked serrate } \\
\text { setae. }\end{array}$ \\
\hline Telson & naked & naked & Sparse simple setae \\
\hline \multicolumn{4}{|l|}{ Antennule } \\
\hline Inner flagellum & Unsegmented, 5 simple setae & Unsegmented, 6 simple setae & Unsegmented, 5 simple setae \\
\hline Outer flagellum & 4-segmented, 8,8,6, 3 aesthetascs & 5 -segmented, $0,8,8,6,3$ aesthetascs & 5 -segmented, $0,5,6,4,0$ aesthetascs \\
\hline Antenna & 9-segmented & 8-segmented & $\begin{array}{l}\text { 8-segmented, 0,0,0, 3, 0, 2, } 4 \text { simple } \\
\text { setae }\end{array}$ \\
\hline Mandibular palp & 2-segmented, 13 simple setae & 2-segmented, 13 plumose setae & 2 -segmented, $11-12$ plumose seate \\
\hline \multicolumn{4}{|l|}{ Maxillule } \\
\hline Protopod & 3 plumose setae & 2 plumose setae & 2 plumose setae \\
\hline Endopod & 2-segmented with 2, 2 simple setae & 2plumose setae, 2 simple setae & $\begin{array}{l}\text { 2-segmented with } 2 \text { plumose setae, } \\
\text { 2simple setae }\end{array}$ \\
\hline \multicolumn{4}{|l|}{ Maxilla** } \\
\hline Endopod & 8 plumose setae & 6 plumose setae & 4 plumose setae \\
\hline Exopod & 55 plumose setae & 49-55 plumose setae & $\begin{array}{l}58 \text { plumose setae }+6 \text { simple setae on } \\
\text { blade }\end{array}$ \\
\hline \multicolumn{4}{|l|}{ First maxilliped } \\
\hline Endopod & 11 plumose setae & 6 simple setae & 1 plumose setae, 5 simple setae \\
\hline Exopod & 2,6 plumose setae & 3 plumose setae, 1 simple seta & 2,3plumose setae \\
\hline Epipod & 16 simple setae & 2 plumose setae, 12 simple setae & 18-19 simple setae \\
\hline \multicolumn{4}{|c|}{ Second maxilliped** } \\
\hline Protopod & 4 plumose setae & 3 plumose setae & 2plumose setae,2 simple setae \\
\hline Endopod & $2,0,6,8$ plumose setae & $2,1,4,7$ plumose setae & $\begin{array}{l}1,1 \text { simple setae,4-5,2-3plumose setae, } \\
5 \text { serrate setae }\end{array}$ \\
\hline Exopod & 4 plumose setae & 4 plumose setae & 4 plumose setae \\
\hline
\end{tabular}


Table II. Continued.

\begin{tabular}{|c|c|c|c|}
\hline Characters & $\begin{array}{c}\text { Hepatus epheliticus } \\
\text { Costıow \& Boокноuт (1962) }\end{array}$ & $\begin{array}{l}\text { Hepatus pudibundus } \\
\text { RIEGER \& HEBLING (1993) }\end{array}$ & $\begin{array}{l}\text { Hepatus pudibundus } \\
\text { Present study }\end{array}$ \\
\hline \multicolumn{4}{|c|}{ Third maxilliped** } \\
\hline Endopod & $26,9,5,8,7$ plumose setae & $21-23,14-15,9,9,7$ plumose setae & $\begin{array}{l}\text { 6-8simple setae, } 18 \text { plumose setae, } 7-9 \\
\text { plumose setae and } 3 \text { simple setae, } \\
3,1 \text { plumose setae, } 9 \text { serrate setae and } 1 \\
\text { simple setae, } 5-6 \text { serrate setae }\end{array}$ \\
\hline Exopod & 6,2 plumose setae & 6,1 plumose setae & 5 simple setae \\
\hline Epipod & 6 plumose setae, 11 simple setae & 4 plumose setae, 9-10 simple setae & 1 plumose setae, 14 simple setae \\
\hline \multicolumn{4}{|l|}{ Pleopods** } \\
\hline Exopod & - & $\begin{array}{l}\text { 14-15, 14-16, 14-15, 12-14 plumose } \\
\text { setae }\end{array}$ & $19,19,16,13$ plumose setae \\
\hline \multicolumn{4}{|l|}{ Uropod } \\
\hline Protopod & - & 1 plumose seta* & 1 plumose seta \\
\hline Exopod & - & 9 plumose setae* & 8-9 plumose setae \\
\hline
\end{tabular}

* obtained from original drawings; ${ }^{* *}$ means differences between HEBLING \& RIEGER (2003) and present descriptions; - not described.

pods cannot be compared as the original description of $H$. epheliticus does not include setation details.

Intraspecifically, the most striking morphological differences between the megalopa of the study by Rieger \& Hebling (1993) and the present description for $H$. pudibundus are as follows: chelipeds and pereiopods (P2 to P4) with 10 plumose setae on basis; pereiopods (P2 to P5) with serrate setae on ventral margin of dactyls; scaphognathite with 58 marginal plumose setae and six simple setae on its blade surface; presence of serrate setae on endopod of second and third maxilliped; 19, 19, 16 and 13 plumose setae on exopods from first to fifth pleopods.

In general, the morphological development of juveniles was similar to that found by Hebling \& Rieger (2003) and details are not presented here. With respect to the juvenile growth of earlier juvenile specimens of the present study are slightly larger (CW) than those obtained by HeBLING \& RIEGER (2003). After the $4^{\text {th }}$ juvenile stage this difference increases. However, the intermolt period for juveniles of the present study is shorter.

Growth under laboratory conditions can be affected by various external factors, such as temperature and food supply (HARTNOLl 2001). Considering that the laboratorial conditions (mean temperature, photoperiod, salinity, and food supply) were similar in both studies, the differences observed could be the result of laboratory versus conditions in the wild by larvae prior to the megalopa stage. In support of this conclusion, Welch \& EPIfanio (1995), in a study of the variation in prey abundance on growth and development of crab larvae, found a great difference existent between specimens from the laboratory and field enclosures. That study demonstrated that larvae are very sensitive to low prey abundance, decreasing the survival, development and dry-weight growth rates in comparison with field conditions.
In this sense, juveniles obtained from laboratory-reared larvae with a longer intermolt period might be expected, as a reduction in energy reserve almost invariably extends the intermolt period resulting in a substantially reduced growth increment (HARTNOLL 2001) in the subsequent molt.

These results point to the problem of extrapolating laboratory data to the field and to the importance of utilizing methodologies that minimize laboratory effects and consequently, the bias over the field estimation.

\section{ACKNOWLEDGEMENTS}

We thank FAPESP (\#04/15194-6) for financial support during field and laboratory activities, and NEBECC members for their help during samplings and laboratory rearings.

\section{LITERATURE CITED}

Costlow JR, J.D. \& C.G. Boокhout. 1962. The larval development of Hepatus epheliticus (L.) under laboratory conditions. Journal of the Elisha Mitchell Scientific Society 78: 113125.

Hartnoll, R.G. 2001. Growth in crustacea - twenty years on. Hydrobiologia 449: 111-122.

Hebling, N.J. \& P.J. Rieger. 2003. Desenvolvimento juvenile de Hepatus pudibundus (Herbst) (Crustacea, Decapoda, Calappidae), em laboratório. Revista Brasileira de Zoologia 20 (3): 531-539.

Mantelatto, F.L.M. \& A. Fransozo. 1992. Relação peso/largura da carapaça do caranguejo Hepatus pudibundus (Herbst, 1785) (Crustacea, Decapoda, Calappidae) na região de Ubatuba, SP, Brasil. Brazilian Archives of Biology and Technology 35 (4): 719-724. 
Mantelatto, F.L.M. \& A. Fransozo. 1994. Crescimento relativo e dimorfismo sexual em Hepatus pudibundus (Herbst, 1785) (Crustacea, Decapoda) no litoral norte paulista. Papéis Avulsos de Zoologia 39 (4): 33-48.

Mantelatto, F.L.M. \& M. Petracco. 1997. Natural diet of the crab Hepatus pudibundus (Herbst, 1785) (Brachyura: Calappidae) in Fortaleza bay, Ubatuba (SP), Brazil. Journal of Crustacean Biology 17 (3): 440-446.

Mantelatto, F.L.M.; A. Fransozo \& M.L. Negreiros-Fransozo. 1995a Distribuição do caranguejo Hepatus pudibundus (Herbst, 1785) (Crustacea, Decapoda, Brachyura) na Enseada da Fortaleza, Ubatuba (SP), Brasil. Boletim do Instituto Oceanográfico 43 (1): 51-61.

Mantelatto, F.L.M.; A. Fransozo \& M.L. Negreiros-Fransozo. 1995b Population structure of Hepatus pudibundus (Herbst, 1785) (Crustacea, Decapoda, Calappidae) in Fortaleza bay, Ubatuba (SP), Brazil. Revista de Biologia Tropical 43 (1-3): 265-270.

Melo, G.A.S. 1996. Manual de identificação dos Brachyura (Caranguejos e siris) do litoral brasileiro. São Paulo, Ed. Plêiade, 603p.

NG, P.K.L.; D. Guinot \& P.J.F. Davie. 2008. Systema Brachyurorum: Part I. An annotated checklist of extant Brachyuran crabs of the world. The Raffles Bulletin of Zoology 17: 1286.

Pohle, G.W. \& M. Telford. 1981. Morphology and classification of decapod crustacean larval setae: A scanning electron microscope study of Dissodactylus crinitichelis Moreira, 1901
(Brachyura: Pinnotheridae). Bulletin of Marine Science 31: 736-752.

Pohle, G.W.; F L.M. Mantelatto; M.L. Negreiros-Fransozo \& A. Fransozo. 1999. Decapod larvae, p. 1281-1351. In D. BoltovsKOY (Ed.). South Atlantic Zooplankton. Rotterdam, Balkema Books, $1^{\text {st }}$ ed., vol. 2, XII+1075p.

Reigada, A.L.D. \& M.L. Negreiros-Fransozo. 1995. Fecundidade do caranguejo Hepatus pudibundus (Herbst, 1785) (Crustacea, Decapoda, Calappidae) em Ubatuba (SP), Brasil. Brazilian Archives of Biology and Technology 38 (2): 661-668.

Reigada, A.L.D. \& M.L. Negreiros-Fransozo. 1999. Maturidade sexual em Hepatus pudibundus (Herbst, 1785) (Crustacea, Decapoda, Calappidae). Iheringia, Série Zoologia, (86): 159164.

Reigada, A.L.D.; M.L. Negreiros-Fransozo \& F.L.M. Mantelatto. 1994. Avaliação do tamanho dos quelípodos de Hepatus pudibundus (Herbst, 1785) (Crustacea, Calappidae) em relação ao sexo e à maturação. Brazilian Archives of Biology and Technology 37 (4): 797-807.

Rieger, P.J. \& N.J. Hebling. 1993. Desenvolvimento larval de Hepatus pudibundus (Herbst, 1785) (Decapoda, Calappidae) em laboratório. Revista Brasileira de Biologia 53 (4): 513528.

Welch, J.M. \& C.E. Epifanio. 1995. Effect of variation in prey abundance on growth and development of crab larvae reared in the laboratory and in large field-deployed enclosures. Marine Ecology Progress Series 116: 55-64.

Submitted: 16.IV.2008; Accepted: 28.XI.2008.

Editorial responsibility: Marcos D.S. Tavares 